\title{
¿A IGUAL RAZÓN, IGUAL DERECHO? LA TUTELA CONSTITUCIONAL DEL INVERSIONISTA NACIONAL POR EXPROPIACIONES INDIRECTAS
}

\section{SAME REASON, SAME RIGHT? THE CONSTITUTIONAL GUARDIANSHIP OF THE NATIONAL INVESTOR FOR INDIRECT EXPROPIATIONS}

* Especializado en Derecho Constitucional y Derecho Procesal, con 24 años de ejercicio profesional y 17 de docencia universitaria. Candidato a Doctor en Derecho por la Pontificia Universidad Católica del Perú (PUCP) y Magíster en Derecho con Mención en Política Jurisdiccional por la misma Universidad. Abogado por la Universidad de San Martín de Porres. Profesor de la Maestría en Derecho Procesal de la PUCP, así como de la Facultad de Derecho y de la Maestría en Derecho Constitucional de la Universidad de San Martín de Porres (USMP). Miembro del Instituto Iberoamericano de Derecho Procesal. Miembro del Consejo Consultivo de la Comisión de Constitución y Reglamento del Congreso de la República. Ex Profesor de la Academia de la Magistratura. Ex Jefe de Gabinete de la Presidencia y la Mesa Directiva del Congreso de la República (2011- 2012). Fundador del Grupo LF Legal. Socio Principal del Estudio Luciano López Flores \& Abogados. Miembro del llustre Colegio de Abogados de Lima (Registro C.A.L. N ${ }^{\circ}$ 24795). luciano@lopezfloresfirna.com

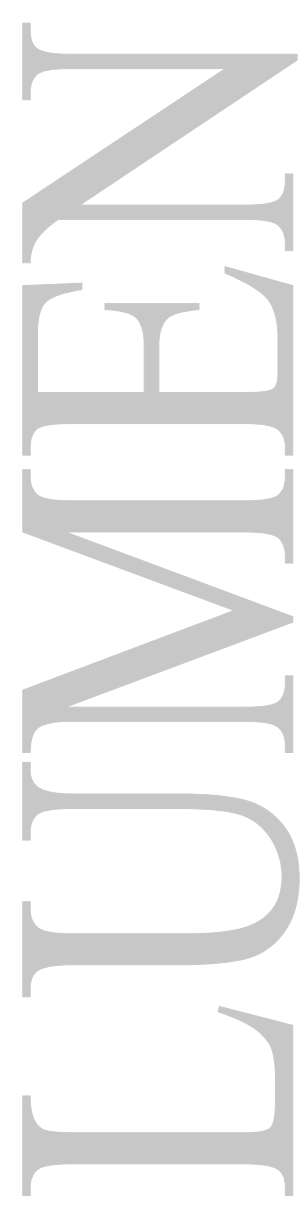




\title{
¿A IGUAL RAZÓN, IGUAL DERECHO? LA TUTELA CONSTITUCIONAL DEL INVERSIONISTA NACIONAL POR EXPROPIACIONES INDIRECTAS
}

\author{
SAME REASON, SAME RIGHT? THE CONSTITUTIONAL GUARDIANSHIP OF THE \\ NATIONAL INVESTOR FOR INDIRECT EXPROPIATIONS
}

Luciano López Flores

\begin{abstract}
Para mi esposa y mi hijo,
Luciano López Febres
\end{abstract}

\begin{abstract}
SUMARIO
1. Recuento de un caso real, a modo de introducción 2. La igualdad de los derechos del inversionista nacional y extranjero en la Constitución y el caso de los TBls y TLCs 2.1. La inversión nacional y extranjera en las Constituciones de 1979 y 19932.2. ¿Qué es "Inversión"? 2.3. Los Tratados Bilaterales de Inversión (TBIs) y los Tratados de Libre Comercio (TLCs) 3. El inversionista extranjero, ¿tiene más ventajas, más derechos que protegen su inversión versus el inversionista nacional, a la luz de los TBls y TLCs suscritos por el Perú? 4. La protección procesal del inversionista nacional ante la expropiación indirecta 4.1. Introducción 4.2. El Proceso de Amparo y la jurisprudencia del Tribunal Constitucional sobre la expropiación indirecta 4.3. ¿Puede recurrir el inversionista nacional al arbitraje de inversiones? 5. Reflexiones Finales 6. Bibliografía
\end{abstract}

\section{RESUMEN:}

En este trabajo se aborda la tesis de la tutela de expropiaciones indirectas de inversionistas nacionales, invocando la igualdad de trato — con las ventajas, derechos y garantías del inversionista extranjero- que establece el artículo $63^{\circ}$ de la Constitución peruana. El objetivo consiste en dejar constancia de las razones por las que cabe ahora avanzar en materia de protección procesal del inversionista nacional frente a los casos de expropiaciones indirectas, más allá de la consolidación del uso del proceso de amparo para tal propósito. Se plantea que esa otra tutela procesal sea aquella que deriva de los Tratados Bilaterales de Inversión y Tratados de Libre Comercio que prevén el arbitraje nacional o internacional en materia de inversiones. Dado que este arbitraje emana de fuente legal - puesto que se encuentra consignado en el tratado que forma parte del Derecho Nacional - el inversionista nacional, por igualdad de trato con el inversionista extranjero, tiene derecho, también, a emplear dicha vía.

\section{ABSTRACT:}

This essay deals with the thesis of the protection of indirect expropriations of national investors, invoking the equal treatment — with the advantages, rights and guarantees of the foreign investor- established in article 63 of the Peruvian Constitution. Our goal is to make explicit the reasons why is it now possible to go forward in the procedural protection of the national investor against cases of indirect expropriation, by using arbitration instead of the amparo process for that purpose. This other procedural protection derives from the Bilateral Investment Treaties and Free Trade Agreements that provides for national or international investment arbitration. Given that this arbitration procedure arises from a legal source, the national investor, under the principle of equality of treatment of the foreign investor is also entitled to use it.

\section{PALABRAS CLAVE:}

Igualdad de trato / Inversión extranjera / Inversión nacional / Tratados Bilaterales de Inversión / Tratados de Libre Comercio / Proceso de Amparo / Jurisprudencia Constitucional / Arbitraje de Inversiones

\section{KEY WORDS}

Equal Treatment / Foreign Investment / National Investment / Bilateral Investment Treaties / Free Trade Agreements / Amparo Process / Constitutional Jurisprudence / Investment Arbitration 


\section{Recuento de un caso real, a modo de introducción}

En 1994, un grupo familiar oriundo de una ciudad de la costa norte de nuestro país, decidió realizar una importante inversión agrícola. Para ello, formó una empresa y adquirió alrededor de cuatrocientas hectáreas de terreno eriazo con el propósito de desarrollar un proyecto de cultivo de espárragos y otros productos para la exportación. Luego de la adquisición de las tierras, iniciaron las gestiones para obtener las licencias que el proyecto requería.

Dentro del espacio territorial adquirido, había un bosque de algarrobos que ocupaba alrededor de ciento cincuenta hectáreas. El Instituto Nacional de Recursos Naturales (INRENA) —entidad encargada de velar por la protección de los bosques naturales-comunicó al grupo inversor que se trataba de un área protegida $\mathrm{y}$, por tanto, intangible.

Como quiera que también debían recabar una licencia de parte del Instituto Nacional de Cultura (INC) de inexistencia de restos arqueológicos, la empresa de este grupo familiar inició el procedimiento administrativo respectivo. EI INC respondió que, del área total de terreno adquirido, alrededor del $60 \%$ tenía presencia de restos arqueológicos de una importante y antigua civilización pre-inca, cuyos trabajos de excavación nunca se habían realizado, pero que figuraban dentro del mapa de zonas arqueológicas de la Región Lambayeque. Por consiguiente, el INC no expidió la licencia.

El proyecto para el cual se adquirió el terreno de cuatrocientas hectáreas se vio imposibilitado de desarrollarse dado que no contaba con las licencias de INRENA y del INC. Ello obligó a analizar la venta del terreno. Había transcurrido un año desde su adquisición generando gastos en la empresa para la tramitación de las licencias que el proyecto requería.

Sin embargo, en 1996 sucedió un hecho inesperado: grupos de personas ingresaron al terreno y tomaron posesión. Mientras la empresa ponía en marcha la maquinaria legal y judicial para expulsarlos, la mora de dichos procedimientos legales no impidió que se incrementara el número de invasores, ocupando la totalidad del terreno. Dichos pobladores, dedicados a la agricultura, talaron el bosque de algarrobos. Lo desaparecieron. Pero eso no fue todo, cualquier vestigio de restos arqueológicos fue saqueado y destruido, dado que cultivaron la tierra haciendo perforaciones de diversos pozos para obtener agua subterránea. La Municipalidad del distrito donde se encuentra el terreno les expidió certificados de posesión y, con ello, las empresas eléctricas y de telefonía, ingresaron al terreno colocando postes y cruzando cables de alta tensión. Los pobladores que habían formado una ciudad de alrededor de 6,000 pobladores aproximadamente, con viviendas de material noble apostadas en el margen de la carretera, se beneficiaron con la instalación de agua potable, luz eléctrica y telefonía. Y, con el tiempo, el programa "Sierra Exportadora" les dio asesoramiento y promocionó los productos que los agricultores cultivaron en la gran extensión de terreno del grupo familiar propietario de dicho inmueble.

Más de diez años estuvo la empresa de este grupo familiar en procesos judiciales de reivindicación con esta población que aprovechando la lentitud de la maquinaria judicial, se apostó en las tierras, destruyó el bosque supuestamente protegido y sumergió en el saqueo y destrucción, cualquier vestigio pre-inca que registraba el mapa de restos arqueológicos del INC. Finalmente, llegado el caso a la Corte Suprema, se dio la razón a la empresa propietaria del terreno y ordenó que los invasores desalojaran las tierras. Presión social tuvo que sufrir la empresa para llegar al desalojo. Plantones, intermediación de autoridades municipales, regionales y hasta Congresales, concurrieron a la zona instalando "mesas de diálogo".

Paralelamente, la empresa, después de una década, reinició los procedimientos administrativos ante INRENA y con el Ministerio de Cultura (antes "INC"), a fin de "desafectar" las áreas que supuestamente estaban "protegidas". 
INRENA, luego de la inspección correspondiente, desafectó el "área protegida". No quedaba rastro de aquel bosque de algarrobos. Había, en su lugar, tierras de cultivo. Por su parte, el Ministerio de Cultura desafectó algunas áreas de las que tenía registrado en su mapa arqueológico, conservando aún alrededor de cien hectáreas. La empresa impugnó tal criterio ante el Poder Judicial, dado que consideraba un abuso que el Estado impidiese al propietario la explotación económica de sus tierras $y$, sin embargo, no hiciera nada porque extraños, sin pedir autorización estatal alguna, saqueen y desaparezcan cualquier vestigio arqueológico para propiciar el cultivo de tierras de propiedad ajena. Y no sólo ello, sino que la empresa también argumentó que el nivel de saqueo de cualquier vestigio era tal que la autoridad administrativa sólo sostenía la existencia a partir del mapa arqueológico, mas no a partir de la realidad.

Este caso, sumariamente relatado, es real. Los propietarios de la empresa, miembros de un grupo familiar, me expusieron el caso hace algún tiempo. La consulta giró en torno a determinar si podían reclamarle al Estado el pago de los daños y perjuicios causados por la prohibición de desarrollar su inversión agrícola debido a la existencia de regulaciones (licencias) que les fueron exigidas pero que, sin embargo, el Estado no exigió, impidió, ni sancionó a la población invasora de terrenos, que destruyó un bosque protegido y, además, los restos arqueológicos existentes en el terreno para proceder a explotar económicamente tierras ajenas.

Como bien anota Velásquez (2013) "la privación indirecta o soterrada de los atributos esenciales de la propiedad o del valor del bien, es lo que se conoce como expropiación indirecta. Figura de origen extranjero que es recogida y aplicada en nuestro sistema jurídico". (p. 46)

En efecto, la aplicación de esta figura ha ido desarrollándose, a paso lento pero seguro, en la jurisprudencia del Tribunal Constitucional y en diversas resoluciones del Instituto Nacional de Defensa de la Competencia y de la Propiedad Intelectual (“INDECOPI").

El ex Magistrado del Tribunal Constitucional, César Landa, en el fundamento $31^{\circ}$ de su precursor voto singular consignado en la STC N 01735-2008-PA/TC (Caso Shougang Hierro Perú S.A.A.), señalaba con propiedad que la Constitución no contiene una prohibición expresa de las expropiaciones indirectas. Sin embargo:

"Ello no significa que la Constitución las tolere. Una interpretación constitucional válida nos lleva a que toda vez que la Constitución reconoce, respeta y protege el derecho de propiedad de los privados como parte del modelo de economía social de mercado al que se adscribe y al establecer la exigencia de un adecuado procedimiento expropiatorio que incluya un pago en efectivo de indemnización justipreciada para intervenir sobre la propiedad de privados, las expropiaciones indirectas se encuentran proscritas. Encontramos que las bases constitucionales que fundamentan la protección contra las expropiaciones regulatorias o indirectas se encuentran en el artículo $70 .^{\circ}$, el artículo $2 .^{\circ}$, inciso 2 , el artículo $63 .^{\circ}$, el artículo 71. ${ }^{\circ}$ y el artículo $61 .^{\circ}$ de la Constitución".

Siendo más específico que el parecer del ex Magistrado Landa Arroyo, en mi concepto la protección contra las expropiaciones indirectas se manifiesta, principalmente, en la defensa del derecho de propiedad, y en la conjugación con la protección de las libertades económicas del propietario: de empresa, trabajo e industria (artículo $59^{\circ}$ de la Constitución).

Pero eso no es todo. Creo que el principio de igualdad de trato de la inversión nacional y extranjera a que se refiere el artículo $63^{\circ}$ de la Constitución abre la puerta a que la regulación de la expropiación indirecta -incluidos sus mecanismos procesales de protección- que contemplan los diversos Tratados de Libre Comercio ("TLCs") celebrados por el Perú con diversos países extranjeros, pueda ser invocada por el inversionista nacional. 
De antemano señalo que, como también lo he dicho en otra oportunidad (López, 2017: p. 15), no debe confundirse proceso constitucional con caso constitucional. Este último atañe a aquella situación fáctica en la que acontece la necesidad de proteger los derechos fundamentales ante una violación o amenaza de violación de tales derechos, independientemente de la vía procesal empleada por la víctima para tutelarlos. Por tanto, los casos constitucionales no son patrimonio exclusivo de los denominados procesos constitucionales.

Digo esto puesto que en este trabajo voy a sostener que los casos de expropiación indirecta son casos constitucionales. Y su protección procesal no sólo acontece en un proceso de amparo. Es más, voy a sostener en este trabajo que de acuerdo al principio-derecho de igualdad de trato entre el inversionista nacional y extranjero que contempla el artículo $63^{\circ}$ de la Constitución, el primero tiene derecho no sólo a invocar la más beneficiosa regulación de expropiación indirecta contemplada en cualquiera de los TLCs celebrados por el Estado Peruano, sino que también tiene derecho a elegir las vías de solución de conflictos contempladas en dichos tratados, es decir, las vías arbitrales nacionales o de arbitraje internacional (CIADI) en materia de inversiones.

Y, en ese sentido, el empleo del proceso constitucional de Amparo quedará expedito ante situaciones en las que el inversionista nacional afectado decida, solamente, recurrir a la justicia constitucional para obtener un mandato judicial que ordene reponer las cosas al estado anterior a la violación de sus derechos fundamentales a costa de la expropiación indirecta.

Esta es la hipótesis que manejaré en este breve trabajo y que desarrollaré a continuación.

\section{La igualdad de los derechos del inversionista nacional y extranjero en la Constitución y el caso de los TBls y TLCs}

\subsection{La inversión nacional y extranjera en las Constituciones de 1979 y 1993}

Las Constituciones del Perú del siglo XIX y XX no contenían disposiciones que, con claridad, establecieran la equivalencia de trato de los inversionistas nacionales y extranjeros, salvo los casos de las dos últimas del siglo pasado: de 1979 y 1993, respectivamente.

En efecto, el artículo $137^{\circ}$ de la Constitución de 1979 señalaba que la inversión extranjera directa era complementaria de la nacional, siempre que estimule el empleo, la capitalización del país, la participación del capital nacional y contribuya al desarrollo. De allí que el Estado debía autorizarla, registrarla y supervisarla. ${ }^{1}$ Desde luego, el tenor de dicha disposición muestra que la inversión extranjera no tenía un status igualitario a la inversión nacional. Claramente esta última tenía preferencia. La inversión extranjera, por tanto, estaba restringida y controlada.

Sin embargo, el 21 de marzo de 1991 fue suscrita en nuestro país la Decisión № 291 de la Comisión del Acuerdo de Cartagena. En sus fundamentos se destaca la reunión celebrada por los Presidentes de los países miembros de dicho espacio regional en La Paz, Bolivia, los días 29 y 30 de noviembre de 1990, en la cual:

"Expresaron su beneplácito por la "convergencia creciente entre las políticas económicas de los Países Andinos en la búsqueda de una mayor eficiencia y competitividad de sus economías, mediante la liberalización y apertura al comercio y la inversión internacional, en la línea de los

\footnotetext{
Constitución Política del Perú de 1979

"Artículo $137^{\circ}$. El Estado autoriza, registra y supervisa la inversión extranjera directa y la transferencia de tecnología foránea como complementarias de las nacionales, siempre que estimulen el empleo, la capitalización del país, la participación del capital nacional, y contribuyan al desarrollo en concordancia con los planes económicos y la política de integración".
} 
intereses de nuestros países, y la implantación de una racionalidad económica fundada en la iniciativa privada, en la disciplina fiscal y en un Estado redimensionado y eficaz".

Es por ello que en el numeral $2^{\circ}$ del Capítulo II de la Decisión N² 291 se dispuso:

"Los inversionistas extranjeros tendrán los mismos derechos y obligaciones a los que se sujetan los inversionistas nacionales, salvo lo dispuesto en las legislaciones de cada País Miembro".

Así, en la senda de lo establecido a nivel regional en la Decisión № 291, el 13 de noviembre de 1991 fue publicado el Decreto Legislativo N 757, Ley Marco para el Crecimiento de la Inversión Privada, que en sus artículos $12^{\circ}$ y $13^{\circ}$ dispusieron la eliminación de tratos diferenciados o discriminatorios entre los inversionistas nacionales o extranjeros ${ }^{2}$.

En ese sentido, cuando la Constitución de 1993 consagró en su artículo $63^{\circ}$ la igualdad de trato entre la inversión nacional y extranjera, enfatizando que ambas se sujetan a las mismas condiciones ${ }^{3,}$ salvo en materia de propiedad o posesión de tierras, bosques, agua, minas, combustibles o fuentes de energía dentro de los cincuenta kilómetros de frontera (artículo $\left.71^{\circ}\right)^{4}$, el camino iniciado dos años antes a nivel regional, terminó de marcar distancia con los controles y restricciones a la inversión extranjera establecidos en la anterior Carta Constitucional.

Ahora bien, ese sometimiento "a las mismas condiciones" debe entenderse a aquellas demarcadas por la propia Constitución en sus artículos $60^{\circ}$ y $61^{\circ}$; es decir, que la actividad empresarial, pública

\section{Decreto Legislativo $N^{\circ} 757$, Ley Marco para el Crecimiento de la Inversión Privada}

"Artículo 12.- El Estado no establece tratamientos discriminatorios ni diferenciados en materia cambiaria, precios, tarifas o derechos no arancelarios, entre los inversionistas y las empresas en que éstos participen ni basándose en sectores o tipo de actividad económica o en la ubicación geográfica de las empresas. Tampoco podrá establecerlos entre las personas naturales nacionales o extranjeras.

Ninguna autoridad, funcionario o empleado del Gobierno Central, Gobiernos Regionales o Locales en cualesquiera de sus niveles, ni empresas del Estado, podrá establecer o aplicar tratamientos discriminatorios ni diferenciados, de conformidad con lo dispuesto en el presente artículo, bajo responsabilidad.

Artículo 13.- De conformidad con lo prescrito en el último párrafo del artículo 126 de la Constitución Política, declárase de necesidad nacional la inversión privada, nacional y extranjera, en actividades productivas realizadas o por realizarse en las zonas de frontera del país. En consecuencia, las personas naturales y jurídicas extranjeras podrán adquirir concesiones y derechos sobre minas, tierras, bosques, aguas, combustibles, fuentes de energía y otros recursos que sean necesarios para el desarrollo de sus actividades productivas dentro de cincuenta kilómetros de las fronteras del país, previa autorización otorgada mediante resolución suprema refrendada por el Ministro que ejerza la Presidencia del Consejo de Ministros y el Ministro del Sector Correspondiente. Dicha resolución suprema podrá establecer las condiciones a las cuales se sujeta la adquisición o explotación.

Las autoridades sectoriales competentes otorgarán las concesiones y otras formas de autorización para la explotación de recursos naturales ubicados dentro de cincuenta kilómetros de las fronteras del país en favor de las personas naturales o jurídicas extranjeras que lo soliciten, previo cumplimiento de las disposiciones legales aplicables y luego de verificar que se hayan expedido la resolución suprema a la que se refiere el párrafo anterior".

3 Constitución Política del Perú de 1993

"Artículo $63^{\circ}$. La inversión nacional y la extranjera se sujetan a las mismas condiciones. La producción de bienes y servicios y el comercio exterior son libres. Si otro país o países adoptan medidas proteccionistas o discriminatorias que perjudiquen el interés nacional, el Estado puede, en defensa de éste, adoptar medidas análogas.

En todo contrato del Estado y de las personas de derecho público con extranjeros domiciliados consta el sometimiento de éstos a las leyes y órganos jurisdiccionales de la República y su renuncia a toda reclamación diplomática. Pueden ser exceptuados de la jurisdicción nacional los contratos de carácter financiero.

El Estado y las demás personas de derecho público pueden someter las controversias derivadas de relación contractual a tribunales constituidos en virtud de tratados en vigor. Pueden también someterlas a arbitraje nacional o internacional, en la forma en que lo disponga la ley".

4 Constitución Política del Perú de 1993

"Artículo $71^{\circ}$. En cuanto a la propiedad, los extranjeros, sean personas naturales o jurídicas, están en la misma condición que los peruanos, sin que, en caso alguno, puedan invocar excepción ni protección diplomática. Sin embargo, dentro de cincuenta kilómetros de las fronteras, los extranjeros no pueden adquirir ni poseer por título alguno, minas, tierras, bosques, aguas, combustibles ni fuentes de energía, directa ni indirectamente, individualmente ni en sociedad, bajo pena de perder, en beneficio del Estado, el derecho así adquirido. Se exceptúa el caso de necesidad pública expresamente declarada por decreto supremo aprobado por el Consejo de Ministros conforme a ley". 
o no pública, recibe el mismo tratamiento legal, y, además, que el Estado facilita y vigila la libre competencia. Y esto sin contar el igual tratamiento en cuanto a sus formas de resolución de conflictos, puesto que los artículos $62^{\circ}$ y $63^{\circ}$ reconocen la alternatividad de recurrir a la solución de conflictos en la vía arbitral (nacional o internacional) o judicial, según esté pactado en el contrato o lo establezca la ley.

\section{2. ¿Qué es "Inversión"?}

Es lógico suponer que una Constitución no va a definir lo que debe entenderse por inversión. Así que las Cartas de 1979 y 1993 no contienen una definición al respecto.

El Decreto Legislativo № 757, aprobado dos años antes de la Constitución de 1993, no contempló una definición clara y precisa de inversión, aunque del texto de su artículo $5^{\circ}$ puede identificarse que ésta se organiza a través de cualquier forma empresarial para la realización de cualquier actividad económica específica ${ }^{5}$.

Sin embargo, en el numeral $1^{\circ}$ del Capítulo I de la Decisión № 291 del Acuerdo de Cartagena, se establecieron definiciones de lo que debe entenderse por inversión extranjera directa y nacional ${ }^{6}$ identificándose a aquella realizada en aportés de capital en empresas, en bienes o moneda, realizadas por extranjeros residentes en un país o por los nacionales.

Ramírez y Flórez (2006, p.4) usan la siguiente definición de inversión extranjera directa realizada por UNCTAD (División de las Naciones Unidas para el Comercio y el Desarrollo), asumida en su totalidad en el año 2005 por la OECD, Organization for Economic Co- operation and Development:

\section{Decreto Legislativo $\mathbf{N}^{\circ} \mathbf{7 5 7}$, Ley Marco para el Crecimiento de la Inversión Privada}

“Artículo 5. El Estado garantiza el pluralismo económico. Toda empresa tiene el derecho de organizarse bajo cualquier forma empresarial en la legislación nacional. No puede limitarse el acceso directo o indirecto de los inversionistas o las empresas en que estos participen a actividades económicas específicas, en función a la forma empresarial que adopten. Están exceptuados de esta disposición el sistema financiero de acuerdo a la Ley que lo regula, y las excepciones que en el futuro se establezcan por Ley del Congreso. Queda derogada toda disposición legal que contravenga lo dispuesto en el presente artículo. En los casos en que la Ley establezca que la explotación de los recursos naturales o la prestación de los servicios públicos deba realizarse mediante concesiones u otras formas de otorgamiento a los particulares, se respetará lo dispuesto en el presente Decreto Legislativo en lo que no contravenga la legislación sectorial".

\section{Decisión $N^{\circ} 291$ del Acuerdo de Cartagena}

\section{"Capítulo I. Definiciones}

1. Para los efectos del presente Régimen se entiende por:

Inversión Extranjera Directa: Los aportes provenientes del exterior de propiedad de personas naturales o jurídicas extranjeras al capital de una empresa, en moneda libremente convertible o en bienes físicos o tangibles, tales como plantas industriales, maquinarias nuevas y reacondicionadas, equipos nuevos y reacondicionados, repuestos, partes y piezas, materias primas y productos intermedios.

Igualmente, se considerarán como inversión extranjera directa las inversiones en moneda nacional provenientes de recursos con derecho a ser remitidos al exterior y las reinversiones que se efectúen de conformidad con el presente Régimen.

Los Países Miembros, de conformidad con sus respectivas legislaciones nacionales, podrán considerar como aporte de capital, las contribuciones tecnológicas intangibles, tales como marcas, modelos industriales, asistencia técnica y conocimientos técnicos patentados o no patentados que puedan presentarse bajo la forma de bienes físicos, documentos técnicos e instrucciones.

Inversionista Nacional: El Estado, las personas naturales nacionales y las personas jurídicas definidas como nacionales por las legislaciones de los Países Miembros.

Se considerarán también como inversionistas nacionales a las personas naturales extranjeras con residencia ininterrumpida en el país receptor no inferior a un año, que renuncien ante el organismo nacional competente al derecho de reexportar el capital y a transferir utilidades al exterior.

El organismo nacional competente del país receptor podrá exonerar a dichas personas del requisito de residencia ininterrumpida no inferior a un año. Cada País Miembro podrá eximir a las personas naturales extranjeras cuyas inversiones se hubieran generado internamente, de la renuncia prevista en el inciso anterior. Asimismo, se considerarán como de inversionistas nacionales, las inversiones de propiedad de inversionistas subregionales, en los términos establecidos en la presente Decisión.

Inversionista Subregional: El inversionista nacional de cualquier País Miembro distinto del país receptor. Inversionista Extranjero: El propietario de una inversión extranjera directa". 
"La inversión extranjera directa refleja el interés de largo plazo de una entidad residente en una economía (inversor directo) en una entidad residente en otra economía (inversión directa). Cubre todas las transacciones entre los inversores directos y la inversión directa, lo cual significa que cubre no sólo la transacción inicial, sino que también las transacciones subsecuentes entre las dos entidades y el resto de empresas afiliadas."

Estos mismos autores (2006, p.5) citan otras dos definiciones de inversión extranjera directa (IED) de suma utilidad. Así, la definición de la OMC (Organización Mundial del Comercio) es la siguiente:

"La inversión extranjera directa ocurre cuando un inversor establecido en un país (origen) adquiere un activo en otro país (destino) con el objetivo de administrarlo. La dimensión del manejo del activo es lo que distingue a la IED de la inversión de portafolio en activos, bonos y otros instrumentos financieros. En la mayoría de los casos, el activo es administrado en el extranjero como firma del mismo negocio. Cuando esto sucede, el inversor se conoce como «casa matriz» y el activo como «afiliada» o «subsidiaria»".

Y, por otro lado, la Agencia Multilateral de Garantías para la Inversión (Banco Mundial) define a la IED de esta manera:

"Inversión extranjera significa adquirir intereses de largo plazo en una empresa que esté operando en otro país diferente al del inversor. El propósito del inversor es el de tener una voz participativa en el manejo de dicha empresa en el extranjero". (Ramírez y Flórez, 2006 p. 5)

Sin embargo, en nuestro medio Carrano y Bonifaz (2011, p.94) señalan que no existe una única definición de lo que constituye una "inversión" que se pueda aplicar de manera general, sino que existen definiciones individuales en los acuerdos de promoción y protección de inversiones, puesto que los intentos por establecer una definición general no han tenido éxito.

\subsection{Los Tratados Bilaterales de Inversión (TBIs) y los Tratados de Libre Comercio (TLCs)}

Bohoslavsky señala que antes de 1917 era mayoritariamente aceptado entre los expertos del derecho internacional que si un Estado se apropiaba de las propiedades de un inversor extranjero estaba obligado a realizar una compensación adecuada y rápida y que por ese motivo no se prestaba demasiada atención a las reglas de protección de las inversiones extranjeras (2010, p.11). Sin embargo, agrega este autor que esa situación cambió radicalmente con la revolución bolchevique, el repudio de la deuda soberana y la abolición de la propiedad privada sin compensación.

"Aquella originaria idea de que la afectación de la inversión extranjera debía compensarse también fue puesta en crisis con la revolución mexicana y el dictado de una nueva constitución nacional en 1917 que consagra (hasta el día de hoy, en su artículo 27) la función pública de la propiedad. (...).

[Y] en forma simultánea con esos sucesos políticos, se desarrolló la llamada doctrina Calvo, que fue propuesta y desarrollada por el jurista argentino homónimo, que sostenía que los inversores extranjeros no gozaban de mayores derechos que los ciudadanos del país que los alojaba. Esta teoría implicaba que si las garantías de los nacionales eran reducidas, se podía hacer otro tanto con las de los extranjeros". (Bohoslavsky, 2010 p.11) 
En el Perú, como bien afirma Rubio (1999, p.301), la denominada cláusula Calvo fue recogida en el artículo $17^{\circ}$ de la Constitución de 19337.

Pero RICO y KUCHARZ (2013) señalan que, a comienzos de los años 90, derribado el muro de Berlín, el Fondo Monetario Internacional (FMI) impuso planes de ajuste estructural para superar la crisis de la deuda latinoamericana, siendo que esa misma década empezó con 385 tratados bilaterales de inversiones (TBI) firmados y acabó con 1,857. Agregan estos autores que ello no fue casualidad, puesto que la inversión extranjera directa que se quería fomentar con las privatizaciones, necesitaba ser protegida de la inestabilidad de los países pobres. Y nada mejor que un TBI para proteger la inversión y con ello fomentarla para alcanzar la "ansiada senda del crecimiento y del desarrollo".

Dicha opinión coincide en parte con la de Bohoslavsky (2010: p.14) quien detalla lo siguiente:

"Ya en la década de los sesenta y a raíz de la abierta discrepancia respecto de los estándares mínimos que componían la costumbre internacional y el fracaso de los esfuerzos diplomáticos tendientes a concluir acuerdos multilaterales en materia de protección de las inversiones extranjeras (UNCTAD, 1998; Dolzer y Schreuer, 2008), y bajo la premisa de que un mayor flujo de capitales extranjeros beneficiaría tanto a países desarrollados como en desarrollo (World Bank, 1992), los países exportadores de capitales comenzaron a motorizar una estrategia más efectiva al compás de la expansión del comercio mundial: la negociación de acuerdos bilaterales con definiciones y pautas genéricas y expresas prórrogas de jurisdicción a favor de tribunales arbitrales (Wälde, 1998).

El primer y gran paso de esa estrategia fue la creación de un sistema de arbitraje para los casos de disputas, siendo el CIADI el más conocido y extendido (Broches, 1972; Lowenfeld, 2007). Los antecedentes de la creación del CIADI explican en gran medida por qué se limitó a ser una convención de normas básicamente procesales, sin definir las reglas materiales precisas que deben regir las disputas entre inversores extranjeros y soberanos: era la única manera de lograr el consenso necesario para que se aprobara la convención. Las reglas de fondo serían definidas luego por los árbitros y — tal como será analizado a lo largo de este trabajo-, finalmente, la jurisprudencia arbitral consagró y expandió la Fórmula Hull".

Y puntualiza el autor que vengo citando:

"Aunque el primer tratado comercial data de 1778 (entre los Estados Unidos y Francia), y ya en 1959 se había firmado el primer TBI moderno (siguiendo el formato tal como se conocen hoy) entre Alemania y Pakistán, fue recién con la aprobación en 1965 de la convención del CIADI que comenzó a configurarse la arquitectura jurídica que sostiene a los modernos TBIs.

Las características centrales de dicha convención son: i) los inversores extranjeros pueden demandar directamente al Estado que los aloja; ii) la inmunidad soberana es restringida substancialmente; iii) el derecho internacional puede ser aplicado a la relación que se entabla entre un inversor extranjero y el Estado en el que se establece; iv) el agotamiento de los remedios locales es excluido, en principio, como exigencia previa al reclamo arbitral; y, v) la ejecución de los laudos es exigible en cualquiera de los países miembros del CIADI.

\footnotetext{
Constitución Política del Perú de 1933

"Artículo 17.- Las Compañías mercantiles, nacionales o extranjeras, están sujetas, sin restricciones, a las leyes de la República. En todo contrato del Estado con extranjeros, o en las concesiones que otorgue aquél en favor de éstos, debe constar el sometimiento expreso de los segundos a las leyes y a los Tribunales de la República y su renuncia a toda reclamación diplomática".
} 
Lo más importante es que el sistema de resolución de disputas entre inversores y Estados es pretendidamente "despolitizado" en el sentido de que, por un lado, el Estado del inversor y el que lo aloja ya no se relacionan directamente puesto que existe un complejo sistema arbitral que los intermedia (Shihata, 1986); y por el otro, porque ese sistema implica la prórroga de jurisdicción a favor de árbitros internacionales que son - pretendidamente - ajenos a las tensiones políticas propias de cualquier sistema judicial doméstico. El argumento que subyace a ese mecanismo de resolución de controversias es la presunción de que los jueces del Estado que recibe la inversión asumen cierta tendencia a beneficiar a su Estado en caso de disputa con ese inversor, con lo que se busca asegurarles a esos inversores un mínimo de garantías de que no serán tratados de manera arbitraria (Lowenfeld, 2008). Además, se suelen presentar dudas acerca de la imparcialidad y capacidad de los sistemas judiciales de países en vías de desarrollo (Vandevelde, 1992).

La expansión cuantitativa de los TBls es impactante: a fines de 2008 habían sido ratificados 2,7 mil TBIs (UNCTAD, 2009). A la tendencia general de promoción de TBls que llevaron adelante los países desarrollados, se sumaron, por un lado, los países asiáticos. Así, entre 1982 y 2006, China ratificó 117 TBIs (Chow, 2003), entre 1994 y 2006, India firmó 56, y a 2006, Japón era parte en 12 TBls (Dolzer y Schreuer, 2008). Y por el otro, en los últimos años se aceleró rápidamente la ratificación de TBls entre países en desarrollo, llegando a superar el número los TBls pactados entre países desarrollados y en desarrollo entre 2003 y 2006 (UNCTAD, 2007)".

El Perú ha celebrado múltiples acuerdos bilaterales y multilaterales destinados a establecer un marco de promoción y protección de la inversión extranjera. La suscripción de la Decisión $\mathrm{N}^{\circ}$ 291 del Acuerdo de Cartagena, el dictado del Decreto Legislativo $N^{\circ} 757$ publicado en 1991 y el artículo $63^{\circ}$ de la Constitución de 1993 han sido los tres pilares jurídicos sobre los que descansa esta política internacional de fomento de la inversión extranjera en el Perú. Como bien afirman CARRANO y BONIFAZ (2011: 25), se han suscrito más de treinta acuerdos internacionales para la promoción y protección de inversiones que comprenden tanto Tratados Bilaterales de Inversión (TBIs) como acuerdos de libre comercio que incluyen capítulos sobre inversiones, siendo que la negociación y celebración del Tratado de Libre Comercio Perú - Estados Unidos es uno de los grandes esfuerzos que el Perú ha realizado en esta materia.

En lo que concierne a los TBIs, ARSEN (2003: pp. 4-5) afirma que estos presentan ciertos elementos fundamentales que no sólo los caracterizan, sino que los conforman sustancialmente ${ }^{8}$. Sin embargo, agrega esta autora que existen diferencias entre los tratados existentes, no obstante lo cual, los elementos mencionados son la columna vertebral en la mayoría de los mismos, siendo además su denominador común (ARSEN, 2003: 5).

Por su parte, en lo que se refiere a los TLCs, CARRANO y BONIFAZ (2011: 25) señalan que contienen protecciones similares a favor del inversionista extranjero, sin embargo, cada acuerdo constituye un régimen particular lo cual implica que los procesos de interpretación que se realicen sobre sus contenidos son autónomos. No obstante, agregan estos autores que:

8 Estos elementos, según la autora citada, son los siguientes:

"a) Los derechos del inversor de uno de los países signatarios para ingresar y establecerse en el otro Estado. En la práctica significa no establecer procedimientos administrativos o burocráticos que demoren o traben el ingreso de las inversiones, como así también la no intervención arbitraria durante el todo el tiempo que conlleve la inversión. b) La obligación por parte del Estado receptor de la inversión de brindar al inversor el tratamiento denominado "estándares mínimos internacionales". Básicamente debe entenderse por esos estándares el denominado tratamiento de nacional o nación más favorecida.

c) El derecho a la libre transferencia de divisa. El Estado receptor se compromete a permitir la libre transferencia de divisas provenientes de las ganancias obtenidas por el inversor, los servicios de préstamos, compensaciones recibidas por expropiación y la surgida de la remuneración recibida por los empleados extranjeros que prestan servicios a raíz de la inversión. 
"En cuanto a las garantías que estos acuerdos usualmente contienen, se pueden observar las siguientes: garantías relacionadas a trato justo y equitativo, nivel mínimo de trato (tratamiento conforme al Derecho Internacional), expropiación, trato nacional, trato de la nación más favorecida y protección y seguridades plenas" (Carrano y Bonifaz, 2011: p.25).

\section{El inversionista extranjero, ¿tiene más ventajas, más derechos que protegen su inversión versus el inversionista nacional, a la luz de los TBls y TLCs suscritos por el Perú?}

De lo tratado anteriormente (supra 2), no cabe duda que el devenir histórico que dio lugar al surgimiento de los TBls y TLCs muestra que su razón de ser fue otorgar seguridades, garantías y protecciones materiales y procesales a los inversionistas extranjeros respecto de sus capitales invertidos en países de economías emergentes pero de riesgos políticos debido a sus inestabilidades políticas.

En ese escenario no considero problemático advertir que el inversionista extranjero, en el Perú, cuyos capitales están garantizados y protegidos por un TBI o TLC suscrito con el Estado que corresponda al país de proveniencia, tiene más ventajas y derechos frente al inversionista nacional.

Sin embargo, repasemos el tenor del enunciado contenido en el primer párrafo del artículo $63^{\circ}$ de la Constitución: "La inversión nacional y extranjera se sujetan a las mismas condiciones". Y esas condiciones, como antes indiqué (supra 2.1.) deben entenderse aquellas demarcadas por la propia Constitución en sus artículos $60^{\circ}$ y $61^{\circ}$; es decir, que la actividad empresarial, pública o no pública, recibe el mismo tratamiento legal; que el Estado facilita y vigila la libre competencia; y que los artículos $62^{\circ}$ y $63^{\circ}$ reconocen la alternatividad de recurrir a la solución de conflictos en la vía arbitral (nacional o internacional) o judicial, según esté pactado en el contrato o lo establezca la ley.

Asimismo, habría también que tomar en cuenta que de conformidad con lo dispuesto por el artículo $55^{\circ}$ de la Constitución, los tratados celebrados por el Estado y en vigor "forman parte del derecho nacional", por lo que los TBls y TLCs suscritos por el Estado Peruano para fomentar, propiciar y proteger la inversión extranjera, tendrían el rango que corresponda al instrumento jurídico por el cual hayan sido aprobados. Así, coincidiendo con RUBIO (1999: 164), tendrán rango de ley los que fueran aprobados por el Congreso mediante Resolución Legislativa o, en su defecto, tendrán rango infralegal aquellos aprobados mediante Decreto Supremo, respectivamente.

Todo lo anterior es importante puesto que considero que si bien los inversores extranjeros tienen garantizadas y protegidas sus inversiones en virtud a los TBls y TLCs celebrados por el Estados Peruano, los cuales están incorporados al derecho nacional; la igualdad de trato que establece el artículo $63^{\circ}$ de la Constitución permitiría que el inversionista nacional reclame que a él también se le apliquen los conceptos de "inversión" previstos en cualquiera de los TBIs o TLCs celebrados por el Estado Peruano con países extranjeros, así como los elementos, garantías y protecciones a las inversiones que dichos tratados contemplan.

d) El derecho de expropiación de los países receptores. El Estado sólo podrá expropiar todo o parte de la inversión, siempre y cuando sea con una finalidad pública, que no revista características de discriminación y que sea acompañada por una compensación total, pagada en una moneda libremente transferible y convertible, es decir en una denominada "moneda dura".

e) La resolución de disputas entre los inversores y el Estado receptor a través de arbitraje internacional. Si no resulta exitosa una negociación entre partes para la resolución del conflicto, tanto Estado como inversor acuerdan resolverlo frente a un árbitro internacional, recayendo generalmente dicha elección en ICSID. LoS acuerdos contemplan asimismo el carácter ejecutivo de los laudos arbitrales".

Tómese en cuenta que ICSID, International Centre for Settlement of Investment Disputes (Centro Internacional para la Resolución de Disputas surgidas de Inversiones) es el organismo creado por el Banco Mundial con el objetivo de diseñar una institución destinada exclusivamente a la resolución de disputas originadas en inversiones entre Estados e inversores, como herramienta para facilitar el flujo de capitales internacionales (ARSEN, 2003: 5). 
No encuentro razón constitucional ni jurídica alguna para considerar lo contrario. Más aún si como ha establecido el Tribunal Constitucional en los fundamentos $23^{\circ}$ y $24^{\circ}$ de la STC $N^{\circ} 01405-$ 2010-AA/TC (caso Corporación Rey S.A.):

"23. La igualdad es un principio derecho reconocido por el inciso 2) del artículo $2^{\circ}$ de la Constitución, según el cual toda persona tiene derecho a la igualdad ante la ley. De este modo, se reconoce un derecho subjetivo a obtener un trato igual aplicable tanto a las personas físicas como a las jurídicas, trato igual que exige que ante supuestos de hecho iguales deben ser aplicadas similares consecuencias jurídicas.

24. En materia económica, el derecho a la igualdad ante la ley y de trato se encuentra reconocido expresamente en los artículos $60^{\circ}$ y $63^{\circ}$ de la Constitución, en los que se señala por una parte que "la actividad empresarial, pública o no pública, recibe el mismo tratamiento legal" y por otra que "la inversión nacional y la extranjera se sujetan a las mismas condiciones". La inversión puede ser definida como aquella acción mediante la cual los agentes económicos e instituciones involucradas en el proceso económico por medio de fondos propios o ajenosrealizan la compra de activos físicos, bonos, acciones, etc., con el propósito de obtener una serie de beneficios futuros. Es decir, significa el ingreso de dinero, insumo, equipos, etc. (STC 0018-2003-AI/TC)".

En la doctrina nacional poco se ha escrito sobre la factibilidad constitucional de que el inversionista nacional invoque la igualdad de trato con el inversionista extranjero y pida la aplicación de las medidas protectoras y garantistas de la inversión de este último, según los diversos TBls y TLCs suscritos por el Estado Peruano y que forman parte del derecho nacional hoy en día. De los que se han referido al tema en nuestro medio son José Daniel AMADO y Bruno AMIEL, Enrique PASQUEL, Víctor SACO Y Raffo VELÁSQUEZ.

AMADO y AMIEL (2005: 67), basándose en el artículo $21^{\circ}$ de la Convención Americana de Derechos Humanos (CADH), señalan que la amplitud del nivel de protección que ofrece al derecho de propiedad la $\mathrm{CADH}$, alude no sólo a la titularidad de los bienes sino también a su uso y disfrute. Por tanto, su redacción protege directamente una forma común de expropiación indirecta que no reviste la forma de una privación, sino que atenta contra el ejercicio pleno de los atributos de la propiedad, por ejemplo, a través de la afectación total o parcial del derecho de usar un bien o de percibir sus frutos. En el caso de una inversión privada en un negocio en marcha, tal afectación del uso y disfrute alude necesariamente a la administración de los bienes y el derecho a percibir sus réditos y dividendos.

PASQUEL (2005: 124), por su parte, ha señalado:

"[Q]ue en nuestro país el derecho constitucional a la igualdad también sirve como fundamento para exigir que las expropiaciones regulatorias reciban el mismo trato que las expropiaciones físicas: si el Estado le reconoce a empresas extranjeras que invierten en nuestro país -a través de BIT- el derecho a ser indemnizadas frente a una expropiación regulatoria, también deberían gozar de ese derecho las empresas nacionales. El artículo 2, inciso 2, de la Constitución establece que toda persona tiene derecho a la igualdad ante la ley. Ello quiere decir que en el Perú el sistema jurídico no puede otorgar distintos derechos a distintas personas, especialmente sobre la base de factores arbitrarios como la nacionalidad o el origen. Esta precisión se ve reforzada por dos disposiciones constitucionales adicionales. Primero, por el artículo 63 de la Constitución que establece que la inversión nacional y la extranjera se sujetan a las mismas condiciones. Segundo, por el artículo 71, que indica que respecto a la propiedad, los extranjeros están en la misma condición que los peruanos. Evidentemente, estas normas constitucionales deben funcionar de dos maneras. Por un lado, garantizan a los inversionistas 
extranjeros que sus derechos serán equivalentes a los nacionales. Y, por otro lado, deben garantizar a los inversionistas nacionales que a ningún extranjero se le concederán derechos mayores que los suyos. Lo contrario afectaría el principio general de igualdad enunciado en el artículo 2 de la Constitución. De lo contrario, como en la granja de Orwell, viviríamos en una sociedad donde todos somos iguales, pero algunos más iguales que otros".

Concretamente, SACO se ha referido a la posibilidad de que el inversionista nacional afectado en su derecho de propiedad a manos de una expropiación directa, reclame que el pago del justiprecio que deba abonarle el Estado sea de acuerdo al valor de mercado y conforme al procedimiento de cálculo previsto en el artículo 10.7 del TLC celebrado con los Estados Unidos. Y agrega este autor:

"Considero que el valor comercial debe entenderse como el valor de mercado. Mi argumento es el siguiente: la obligación de pagar un valor de mercado se encuentra en los capítulos de inversión de los TLC, los TLC son parte del derecho nacional en virtud del artículo $55^{\circ}$ de la Constitución, que además, en su artículo $63^{\circ}$ reconoce que la "inversión nacional y la extranjera se sujetan a las mismas condiciones", por tanto no debería existir discriminación entre ambos tipos de inversión y a ambos, de ser expropiados, se les debería pagar el valor de mercado.

Si bien se piensa que los Acuerdos Internacionales de Inversión siempre tratan de beneficiar al inversionista extranjero sobre el nacional, en virtud de lo dispuesto en nuestra Constitución considero que lo contrario es factible, es decir, que ambos se beneficien de los mismos derechos en materia de compensación. Lo contrario podría fomentar un incentivo para que los propietarios nacionales al verse amenazados por una expropiación traten de vender sus predios a inversionistas extranjeros que conseguirán un mejor precio.

Esta igualdad de derechos entre inversionistas locales y extranjeros nos lleva también a discutir sobre el asunto de la expropiación indirecta" (SACO, 2014)

Y, por su parte, Velásquez (2013: pp. 46-47) sí considera que el inversionista nacional puede invocar la aplicación de la expropiación indirecta prevista en los diversos TBls y TLCs que el Perú ha suscrito con diversos Estados. Dice lo siguiente:

"Precisamente es en los tratados Bilaterales de inversión (en adelante, TBI o BIT por sus siglas en inglés) suscritos por el Perú con otros países, donde se regula la mutua protección que se deben a las inversiones de los nacionales de la contraparte contra las expropiaciones indirectas o contra medidas equivalentes, de efectos similares o de efectos iguales a una expropiación o ante medidas que priven indirectamente de la propiedad. Lo mismo ocurre con los tratados de Libre Comercio (en adelante, TLC o TPA por sus siglas en inglés) suscritos por el Perú donde, además de referirse expresamente a las expropiaciones indirectas o a medidas equivalentes a la expropiación, se detallan los criterios que se deben tener en cuenta para detectar y aplicar este instituto.

De hecho, en la actualidad el mayor desarrollo de esta temática se da a nivel del derecho internacional. Inversionistas extranjeros inician arbitrajes internacionales contra los estados de acogida, alegando que contravienen un tratado de protección de la inversión extranjera al cometer expropiaciones indirectas contra su patrimonio.

Aun cuando algunos TBI o TLC no brinden expresa protección contra las expropiaciones indirectas, eso no enerva la posibilidad del inversionista de solicitar tutela contra ellas. Ello porque el derecho de propiedad, que constituye un principio fundamental del derecho internacional de inversiones, exige tutela contra ese tipo de agresiones. 
Que los tratados internacionales protejan a los inversionistas extranjeros contra las expropiaciones indirectas no significa que solo ellos pueden invocar esa figura. También lo pueden hacer los inversionistas nacionales. eso no solo en virtud del principio-derecho de igualdad (artículo 2, inciso 2, de la Constitución Política) sino porque expresamente el artículo 63 de la Constitución Política dispone que "la inversión nacional y la extranjera se sujetan a las mismas condiciones".

Finalmente, la jurisprudencia administrativa del INDECOPI también ha reconocido la perfecta aplicación de la expropiación indirecta. Así, en el fundamento $12^{\circ}$ de la Resolución $N^{\circ} 1535-2010 /$ SC1-INDECOPI expedida por el Tribunal de la Competencia y de la Propiedad Intelectual (que fue decretada como precedente administrativo vinculante), se ha establecido lo siguiente:

"12. Esta protección [contra la privación de la propiedad establecida en el art. $70^{\circ}$ de la Constitución] fue diseñada específicamente para las expropiaciones tradicionales, pero hoy se admite en el derecho internacional y en la jurisprudencia extranjera que también alcanza a las denominadas "expropiaciones regulatorias o indirectas". Es decir, a actos gubernamentales que afectan el valor de la propiedad, sin despojar formalmente al propietario de su título. Por eso, dicha protección ha sido recogida en los 33 Convenios Bilaterales de Inversión celebrados por el Perú, por el Tribunal Constitucional y defendida por autores nacionales".

\section{La protección procesal del inversionista nacional ante la expropiación indirecta}

\subsection{Introducción}

Que el inversionista nacional, en virtud de lo dispuesto por los artículos $55^{\circ}$ y $63^{\circ}$ de la Constitución, pueda invocar los mecanismos de protección y garantía de las inversiones extranjeras, según lo pactado por el Estado Peruano en los diversos TBls y TLCs que haya celebrado, constituye una poderosa arma frente a los casos de expropiaciones directas e indirectas, así como de las demás ventajas y derechos reconocidos en dichos tratados.

Así, en conjunto, la invocación de aplicación de esos derechos del inversionista extranjero reconocidos en los diversos TBls y TLCs constituyen mecanismos de protección material de las inversiones nacionales.

Al respecto, un tema por demás interesante, y que es el eje de este trabajo, lo constituye la noción de expropiación indirecta. FAIRLIE, QUEIJA y RASMUSSEN (2006: pp.72-73), tomando como referencia la definición empleada por el TLC Perú-Estados Unidos, señalan lo siguiente:

"Según el Anexo 10-B, la expropiación indirecta se da cuando una medida aplicada por el gobierno tiene un efecto equivalente al de una expropiación directa, sin la transferencia formal del título o del derecho de dominio. Para determinar en que casos se da una expropiación indirecta, es necesario hacer una investigación factual, que considere:

"(i) el impacto económico del acto gubernamental, ... que por sí solo, no establece que una expropiación indirecta haya ocurrido; (ii) la medida en la cual la acción del gobierno interfiere con expectativas inequívocas y razonables de la inversión; y (iii) el carácter de la acción gubernamental" (Anexo 10-B Expropiación, literal 3).

De este modo, se protege al inversionista frente a eventuales riesgos no comerciales, como medidas gubernamentales que pudieran afectar la propiedad sobre su inversión, la libre transferencia de los flujos relacionados con la inversión o la normal gestión y explotación de la misma, previendo obligaciones compensatorias. El Estado también deberá compensar 
en caso de contiendas civiles. Se menciona que salvo en circunstancias excepcionales, no constituyen expropiaciones indirectas los actos regulatorios no discriminatorios de una Parte. De este modo, queda poco espacio para la libertad en la aplicación de políticas.

La expropiación indirecta, es uno de los temas más preocupantes sobre la relación entre la protección a la inversión y las políticas de desarrollo de cada país. Bajo este criterio, las medidas aplicadas por el Estado -de manera no discriminatoria- para proteger el medio ambiente, la salud u otros intereses sobre el bienestar público, quedan dentro del alcance de lo que significa una expropiación".

Pero, como también ya se ha visto antes (supra 2.3.), uno de los principales elementos garantistas de las inversiones extranjeras consiste en que la resolución de disputas se resuelva en la vía arbitral, nacional o extranjera, en materia de inversiones. Estos son, en sustancia, los mecanismos de protección procesal de las inversiones nacionales.

Pues bien, en esta parte del presente trabajo, abordaré estos mecanismos procesales orientados a la protección material del inversionista nacional afectado por expropiaciones indirectas.

\subsection{EL PROCESO DE AMPARO Y LA JURISPRUDENCIA DEL TRIBUNAL CONSTITUCIONAL SOBRE LA EXPROPIACIÓN INDIRECTA}

De acuerdo con SUMAR (2014), la Constitución dice que las expropiaciones deben ser compensadas, pero se refiere a las compensaciones "formales", hechas con una ley del Congreso y que quitan del todo la propiedad a los individuos. Sin embargo, para el caso de las expropiaciones regulatorias, la Constitución no dice nada.

Sin embargo, la jurisprudencia constitucional ha ido abriendo camino al reconocimiento de la expropiación indirecta, a pesar que en un inicio negó su existencia en un caso (RTC N 0541-1999AA/TC, Oscar Enrique Morello Silva) donde se analizaba la constitucionalidad de la prohibición de tener grifos en el Centro de Lima, con efectos retroactivos (SÚMAR, 2014).

En efecto, el primer fallo del Tribunal Constitucional (TC) que data del año 2008 donde reconoce y tutela la afectación del derecho de propiedad por expropiaciones indirectas es la STC $\mathrm{N}^{\circ} 01735$ 2008-AA/TC (caso Shougang Hierro Perú S.A.A.), concretamente, en un voto singular del ex Magistrado César Landa Arroyo cuyo fundamento reproduje al inicio de este trabajo (supra 1). En esa oportunidad, al declarar fundada la demanda de amparo, el efecto fue la inaplicación, al caso concreto de la empresa demandante, de los efectos de una Ordenanza Municipal que aprobada un Plan de Desarrollo Urbano que abarcaba espacios territoriales donde la demandante tenía concesiones mineras.

Un segundo fallo ha sido el caso Duke Energy Egenor S (STC N 0834-2010-AA/TC) del 9 de mayo de 2011. En esta sentencia, no se ordenó el pago de una indemnización, sino solo se deshizo la expropiación, tal como así fluye de los fundamentos $39^{\circ}$ a $42^{\circ 9}$.

\section{Dijo el TC lo siguiente:}

"39. Como se aprecia, a pesar de que la actual entidad competente es la Autoridad Nacional del Agua, ésta no ha emitido un solo pronunciamiento con respecto a la Resolución N.$^{\circ} 1$, del 7 de abril de 2007, que suspende la Licencia de Uso de Aguas de la actora; y además, pretende hacer perdurar la situación fáctica de despojo que tal decisión ha generado, al ser ella quien ahora maneja las instalaciones de la empresa en la laguna Parón. Peor aún, mediante la Carta N. ${ }^{\circ}$ 347- 2010-ANA-SG/OAJ, del 6 de julio de 2010, remitida a la actora (fojas 41 del cuadernillo de este Tribunal), la aludida autoridad le manifiesta que:

"(...) los derechos de uso de agua otorgados a su representada se encuentran vigentes y gozan del principio de seguridad jurídica que la Ley de Recursos Hídricos les atribuye. El despojo al cual hace referencia no ha sido cometido por parte de la Autoridad Nacional del Agua, quien por el contrario, vela porque los derechos de uso de agua otorgados a todos los usuarios sean respetados". 
Nuevamente, a través del proceso de amparo, el 5 de noviembre de 2012, el Tribunal Constitucional emitió la STC N0239-2010-AA/TC (caso Promotora e Inmobiliaria Town House S.A.C.). Se trató del tercer fallo en materia de expropiación indirecta.

En su demanda, la empresa recurrente solicitó la inaplicación, a su caso concreto, de la Ordenanza N. ${ }^{\circ}$ 1099-MML, publicada en el diario oficial El Peruano el 12 de diciembre de 2007, la cual aprobó el Reajuste Integral de la Zonificación de los usos del Suelo del Distrito de Chaclacayo. Sostuvo que dicho dispositivo vulneró sus derechos constitucionales de propiedad, al trabajo y a la libertad de empresa. Para demostrarlo, argumentó que a pesar de que era propietaria de varios lotes de terreno del Registro de Predios de Lima, y de haber obtenido la autorización municipal correspondiente para la edificación en dichos predios a través de un Certificado de Zonificación y Vías, hasta el mes de junio del año 2008, la entrada en vigor de la referida ordenanza le ha impedido realizar cualquier tipo de edificación inicialmente autorizada puesto que ha modificado la zonificación del área donde se ubican sus terrenos denominándola "Zona de Protección y Tratamiento Paisajista", área donde están prohibidas tales obras. Además, señaló que dicho cambio, al establecer una clasificación menor al tipo de zona que en aquel entonces tenían los predios, colisiona con el artículo $35^{\circ}$ de la Ordenanza N. ${ }^{\circ}$ 620-MML, que aprueba el Plan Metropolitano de Acondicionamiento Territorial y Desarrollo Urbano de Lima, de los planes urbanos distritales y actualización de la zonificación de los usos del suelo de Lima.

En los fundamentos $10^{\circ}$ a $13^{\circ}$ de esta sentencia, el TC fue enfático en reconocer y tutelar la expropiación indirecta. Transcribo in extenso su contenido debido a su importancia:

"10. Por otro lado, la noción de expropiación indirecta o expropiación regulatoria se aplica tanto en derecho internacional como en derecho interno. Siguiendo múltiples pronunciamientos a través de resoluciones expedidas por tribunales internacionales se ha clasificado a las expropiaciones en dos tipos: directas, es decir, aquellos actos legislativos o administrativos que transfieren el título y la posición física de un bien, e indirectas, es decir, aquellos actos estatales que en la práctica producen una pérdida de la administración, el uso o el control de un recurso, o una significativa depreciación en el valor de los bienes. A su vez, se reconoce que las expropiaciones indirectas se subdividen en expropiación progresiva, que son aquellas donde se produce una lenta y paulatina privación de facultades del derecho de propiedad del inversionista titular, lo que disminuye el valor del activo; y las expropiaciones regulatorias que son aquellas donde la amenaza de vulneración al derecho de propiedad se produce a través de regulación estatal.

40. La realidad, sin embargo, demuestra todo lo contrario y, en ese sentido, y a juicio del Tribunal Constitucional, toda esta situación ha generado una nueva afectación respecto del derecho de propiedad de la actora sobre las instalaciones en la laguna Parón. A decir del Instituto de Defensa de la Competencia y Propiedad Intelectual, ello genera una expropiación indirecta o regulatoria. En efecto, mediante el precedente vinculante recaído en el Expediente N. ${ }^{\circ}$ 1535- 2010/SCI-INDECOPI, publicado el 3 de junio de 2010, fundamento 12, dicha entidad ha dejado establecido que, además de las expropiaciones tradicionales, la protección que prevé el artículo $70^{\circ}$ de la Constitución Política también alcanza a las expropiaciones regulatorias o indirectas, "es decir, a actos gubernamentales que afectan el valor de la propiedad, sin despojar formalmente al propietario de su título".

41. De acuerdo con ello, se advierte que el hecho de que la Autoridad Nacional del Agua se mantenga en posesión de los activos de la empresa actora, a pesar de que ya transcurrió el plazo del estado de emergencia que la legitimaba para usar tales bienes, genera que en la práctica dicha empresa haya perdido la administración, el uso y/o control de sus bienes, es decir, que en forma indirecta ha sufrido una expropiación. 42. En efecto, si bien los actos desarrollados por la Autoridad Nacional del Agua, como por ejemplo, la creación de un Comité de Gestión que maneje las instalaciones en la laguna Parón, no generan un despojo formal del título de la empresa sobre sus instalaciones; pero sí generan un despojo de los atributos que forman parte del contenido esencial del derecho de propiedad. Y es que en las actuales circunstancias, y como antes se ha visto, la empresa demandante no puede ejercer su derecho de propiedad, circunstancia que evidencia el despojo que viene sufriendo en la práctica, lo que supone que este Tribunal Constitucional extienda la tutela constitucional requerida con la finalidad de que también cesen estas nuevas afectaciones". 
11. Así pues a nivel interno, debe entenderse por expropiación indirecta o expropiación regulatoria aquella en donde la Administración Pública a través de una sobrerregulación priva (total o parcialmente) al propietario de un bien de uno o todos los atributos del derecho de propiedad (ya sea del uso, del disfrute o de la disposición). El derecho de propiedad sobre bienes tiene sentido en tanto permite extraer un mayor provecho a los bienes. Si no se puede disponer, usar o disfrutar los bienes, gozar de su titularidad carece de relevancia.

12. Si bien la Constitución no hace mención expresa relativa a la proscripción de las expropiaciones indirectas, lo que no significa que la Constitución las tolere, una interpretación constitucional válida lleva a concluir que toda vez que la Constitución reconoce, respeta y protege el derecho de propiedad de los privados como parte del modelo de economía social de mercado al que se adscribe y al establecer la exigencia de un adecuado procedimiento expropiatorio que incluya un pago en efectivo de indemnización justipreciada para intervenir sobre la propiedad de privados, las expropiaciones indirectas se encuentran proscritas. Al respecto, las bases constitucionales que fundamentan la protección contra las expropiaciones regulatorias o indirectas se encuentran en los artículos $70 .^{\circ}, 2 .^{\circ}$, inciso $2,63 .^{\circ}, 71 .^{\circ}$ y $61 .^{\circ}$ de la Constitución.

13. En consecuencia, se advierte una amenaza cierta e inminente de vulneración al uso y disfrute de la propiedad del recurrente puesto que las medidas adoptadas en la Ordenanza Municipal 1099-MML recortan las legítimas y reales expectativas del demandante, orientadas a darle el uso real y concreto para el cual fue adquirido el predio. Tal como el Tribunal Constitucional ha manifestado: "[...] se trata de un derecho cuyo origen no reside en la voluntad política del legislador estatal, sino en la propia naturaleza humana, que impulsa al individuo a ubicar bajo "su" ámbito de acción y autoconsentimiento, el proceso de adquisición, utilización y disposición de diversos bienes de carácter patrimonial". De la misma forma afirma que "El propietario dispondrá, simultáneamente, del poder de emplear su bien en procura de lograr la satisfacción de sus expectativas e intereses propios y los de su entorno familiar; y el deber de encauzar el uso y disfrute del mismo en armonía y consonancia con el bien común de la colectividad a la que pertenece." (STC Nº008-2003-PI/TC).

Estos tres fallos en los que el Tribunal Constitucional ha declarado fundadas demandas de amparo ante casos de expropiaciones indirectas reflejan que el reconocimiento en el derecho nacional de estos mecanismos existentes en los TBIs y TLCs, aun cuando el TC los desprenda del derecho de propiedad contemplado en el artículo $70^{\circ}$ de la Constitución, abre el espacio suficiente para sostener que la tutela procesal de las inversiones nacionales frente a supuestos de expropiación indirecta es viable a través del proceso de amparo cuando sólo se persiga retornar las cosas al estado anterior a la violación de los derechos fundamentales afectados por tal supuesto de expropiación. Sin embargo, en aquellas situaciones en las que el inversionista nacional desee reclamar una compensación, sostengo que nuevamente invocando la igualdad de trato puede recurrir al arbitraje, usando los mecanismos de resolución de conflictos previstos en los TBIs y TLCs suscritos por el Perú.

Sobre esto me abocaré seguidamente.

\section{2. ¿PUEDE RECURRIR EL INVERSIONISTA NACIONAL AL ARBITRAJE DE INVERSIONES?}

Hemos visto que una de las garantías de los TBIs y TLCs es la resolución de conflictos por vía arbitral. Es más, los artículos $62^{\circ}$ y $63^{\circ}$ de la Constitución le permiten al inversionista resolver los conflictos acudiendo a la vía arbitral o judicial, según lo establezca el contrato o la ley. 
No cabe duda que el arbitraje previsto en los diversos TBls y TLCs resultaría una vía más beneficiosa (sobre todo en cuanto al tiempo y al resguardo absoluto de la imparcialidad) que las del Poder Judicial cuando el inversionista, afectado por una decisión estatal, ve privado su derecho de propiedad a causa de una expropiación indirecta. A pesar que no exista "convenio arbitral", la fuente jurídica de acogimiento a esa vía será el tratado invocado por el inversionista, bien sea un TBI o un TLC.

Dicho de otro modo, cuando el Estado Peruano, al celebrar los TBls y TLCs, ha acordado con otros Estados, resolver los conflictos derivados de la inversión extranjera en el Perú a través del arbitraje nacional o internacional de inversiones, es esa fuente jurídica (el Tratado) la que lo vincula con el arbitraje. Sería absurda una defensa del Estado que argumente falta de "convenio arbitral".

Ahora bien, si a eso le agregamos que el arbitraje, por mandato expreso del inciso $2^{\circ}$ del artículo $139^{\circ}$ de la Constitución, es un espacio jurisdiccional ${ }^{10}$, pues entonces el Estado Peruano, a través de los TBls y TLCs celebrados con otros Estados, se ha sometido, puntualmente, a la jurisdicción arbitral nacional, en los casos que los inversionistas extranjeros no decidan llevar su disputa a un arbitraje en fueros internacionales (CIADI, por ejemplo).

En ese sentido, si por imperio del artículo $63^{\circ}$ de la Constitución el inversionista nacional tiene el mismo trato que el inversionista extranjero, ¿por qué no podía oponerle al Estado no sólo los mecanismos de protección material de los TBIs y TLCs, sino también los procesales, específicamente, la solución del conflicto vía arbitraje, si el Estado ya asumió en virtud a dichos tratados que esa vía procesal es la única en la que deberán resolverse los asuntos vinculados a la inversión extranjera? ¿Necesitaría "convenio arbitral"? Sostengo, rotundamente, que no. El inversionista nacional no necesita de convenio alguno. En la igualdad de trato con el inversionista extranjero, sería absurdo pedirle convenio. El Estado ya se sometió a la jurisdicción arbitral nacional y a la competencia del arbitraje en sede internacional, por imperio de los TBIs y TLCs. Si tanto el inversionista extranjero como el nacional tienen un trato igual, insisto, el inversionista nacional tiene el mismo derecho de invocar los tratados para que el conflicto sobre inversiones se dilucide en sede arbitral, más aún si los tratados, como ya se ha visto, en virtud a lo dispuesto por el artículo $55^{\circ}$ de la Constitución forman parte del derecho nacional.

10 Cuestión que ha sido ratificada por el Tribunal Constitucional en el famoso precedente vinculante recaído en el caso Sociedad Minera de Responsabilidad Ltda. Maria Julia (STC $N^{\circ} 00142-2011-$ PA/TC). Y es que en los fundamentos

11, 12 y 13 de este fallo, el TC ha dicho:

"11. A partir de lo establecido por la norma fundamental, "el arbitraje no puede entenderse como un mecanismo que desplaza al Poder Judicial, ni tampoco como su sustitutorio, sino como una alternativa que complementa el sistema judicial puesta a disposición de la sociedad para la solución pacífica de las controversias. Y que constituye una necesidad, básicamente para la solución de conflictos patrimoniales de libre disposición y, sobre todo para la resolución para las controversias que se generen en la contratación internacional” (STC 6167-2005$\mathrm{PHC} / \mathrm{TC}$, fundamento 10). Desde esta perspectiva, "este Tribunal reconoce la jurisdicción del arbitraje y su plena y absoluta competencia para conocer y resolver las controversias sometidas al fuero arbitral, sobre materias de carácter disponible (...), con independencia jurisdiccional y, por tanto, sin intervención de ninguna autoridad, administrativa o judicial ordinaria" (STC 6167-2005- PHC/TC, fundamento 14).

12. Sin embargo de la especial naturaleza del arbitraje, en tanto autonomía de la voluntad de las partes y, al mismo tiempo, de la independencia de la jurisdicción arbitral, no supone en lo absoluto desvinculación del esquema constitucional, ni mucho menos del cuadro de derechos y principios reconocidos por la Constitución. Como ya ha señalado este Tribunal, "la naturaleza de jurisdicción independiente del arbitraje, no significa que establezca el ejercicio de sus atribuciones con inobservancia de los principios constitucionales que informan la actividad de todo órgano que administra justicia, tales como el de independencia e imparcialidad de la función jurisdiccional, así como los principios y derechos de la función jurisdiccional. En particular, en tanto jurisdicción, no se encuentra exceptuada de observar directamente todas aquellas garantías que componen el derecho al debido proceso" (STC 6167-2005-PHC/TC, fundamento 9).

13. Ello es así por cuanto la función jurisdiccional se sustenta y se debe a la norma fundamental, más allá de la especialidad sobre la que pueda versar o de la investidura de quienes la puedan ejercer. De este modo y aunque se dota a la Justicia arbitral de las adecuadas garantías de desenvolvimiento y se fomenta su absoluta observancia, la misma se encuentra inevitablemente condicionada a que su ejercicio se desarrolle en franco respeto al orden constitucional y a los derechos de la persona". 
Repárese que como ya lo he señalado en un trabajo anterior (López Flores, 2017: p.15), no debe confundirse proceso constitucional con caso constitucional, puesto que este último atañe a aquella situación fáctica en la que acontece la necesidad de proteger los derechos fundamentales ante una violación o amenaza de violación de tales derechos, independientemente de la vía procesal empleada por la víctima para tutelarlos. Por tanto, los casos constitucionales no son patrimonio exclusivo de los denominados procesos constitucionales.

Así, los casos de expropiación indirecta son casos constitucionales. Y su protección procesal no sólo acontece en un proceso de amparo. De acuerdo al principio-derecho de igualdad de trato entre el inversionista nacional y extranjero que contempla el artículo $63^{\circ}$ de la Constitución, el primero tiene derecho no sólo a invocar la más beneficiosa regulación de expropiación indirecta contemplada en cualquiera de los TBIs y TLCs celebrados por el Estado Peruano, sino que también tiene derecho a elegir las vías de solución de conflictos contempladas en dichos tratados, es decir, las vías arbitrales nacionales o de arbitraje internacional (CIADI) en materia de inversiones. Y, por un lado, el empleo del proceso constitucional de Amparo quedará expedito ante situaciones en las que el inversionista nacional afectado decida, solamente, recurrir a la justicia constitucional para obtener un mandato judicial que ordene reponer las cosas al estado anterior a la violación de sus derechos fundamentales a costa de la expropiación indirecta. Y, por otro, la recurrencia al arbitraje nacional será un espacio donde el inversionista nacional podrá abordar el conflicto en toda su magnitud: deberá acreditar que su caso calza en el concepto de inversión prevista en cualquiera de los TBIs y TLCs suscritos por el Estado Peruano y, luego, deberá invocar los mecanismos de protección material. El arbitraje, pues, resulta ser una vía mucho más completa y útil que el amparo, puesto que podrá abordar las compensaciones según los mecanismos acordados por el Estado en los diversos tratados, escogiendo el que mejor le convenga, debido a su derecho de igualdad de trato. Eso sí, insisto, sin olvidar que ese arbitraje de inversiones en sede nacional, es un auténtico caso constitucional por las características y el desarrollo argumentativo que he desarrollado en el transcurso de este trabajo.

\section{REFLEXIONES FINALES}

Lo tratado en este trabajo muestra los avances que se han venido reportando a nivel de la jurisprudencia administrativa y, sobre todo, constitucional, de reconocimiento de la tutela de casos de expropiaciones indirectas de inversionistas nacionales, invocando la igualdad de trato con las ventajas, derechos y garantías del inversionista extranjero que establece el artículo $63^{\circ}$ de la Constitución.

Pero como también lo he señalado en este texto, cabe ahora avanzar en materia de la protección procesal del inversionista nacional frente a los casos de expropiaciones indirectas. La jurisprudencia constitucional muestra que el proceso de amparo es una vía para retornar las cosas al estado anterior al acto estatal que produjo la expropiación, aunque en ese proceso no pueda discutirse la compensación correspondiente.

Es allí que surge el enfoque de la tutela procesal a través de los mecanismos de protección procesal previstos en los TBIs y TLCs consistentes en la solución de conflictos vía arbitraje nacional o internacional en materia de inversiones. Ese arbitraje emana de fuente legal, puesto que se encuentra consignado en el tratado que forma parte del Derecho Nacional por imperio del artículo $55^{\circ}$ de la Constitución y al cual el inversionista nacional, por igualdad de trato con el inversionista extranjero, tiene derecho, también, a recurrir a dicha vía. Sería absurdo pedirle convenio arbitral. No lo necesita. El Estado, en todos y cada uno de los TBIs y TLCs, ya aceptó someter la controversia sobre inversiones en el arbitraje nacional e internacional.

Ese es, ahora, el camino a recorrer. Y, desde luego, el debate está servido. 


\section{BIBLIOGRAFÍA}

- Amado, J. y Amiel, B. (2005) "La expropiación indirecta y la protección de las inversiones extranjeras". En: Themis. Número 50. Lima.

- Arsen, P. (2003) "Tratados bilaterales de inversión. Su significado y efectos"; Buenos Aires: Editorial Astrea; http://direitosp.fgv.br/sites/direitosp.fgv.br/files/anexo10tratadosbilateralesdeinversion.pdf Consultado: 21 de julio de 2017.

- Bohoslavsky, J. (2010) "Tratados de protección de las inversiones e implicaciones para la formulación de políticas públicas (especial referencia a los servicios de agua potable y saneamiento)"; Santiago de Chile: Comisión Económica para América Latina y el Caribe (CEPAL); http://repositorio.cepal.org/bitstream/handle/11362/3769/S2010545 es.pdf?sequence=1\&isA llowed=y Consultado: 21 de julio de 2017.

- Carrano, I. y Bonifaz, G. (2011) "La protección de inversiones del Tratado de Libre Comercio Perú-Estados Unidos. Principales garantías para el inversionista"; Lima: Instituto de Regulación y Finanzas - Ara Editores - Esan.

- Instituto de Defensa de la Competencia y de la Propiedad Intelectual -INDECOPI- (2010) Resolución N 1535-2010/SC1-INDECOPI expedida por el Tribunal de la Competencia y de la Propiedad Intelectual. Lima: 3 de mayo.

- Fairlie, Alan; Queija, Sandra; y, Rasmussen, Milagros (2006) "Tratado de Libre Comercio Perú - Estados Unidos: Un balance crítico"; CISEPA - Pontificia Universidad Católica del Perú y Red Latinoamericana de Comercio Internacional, LATN.

- López Flores, Luciano (2017) "Para evitar el (des)amparo. Cinco pautas para comprender el modelo de la residualidad de los procesos constitucionales"; En: AAVV. "Por qué fracasan los amparos. El uso adecuado de las vías previas y específicas relacionadas con el Amparo"; Lima: Gaceta Jurídica.

- Pasquel Rodríguez, Enrique (2005) "Tomando la propiedad en serio: las expropiaciones regulatorias o indirectas"; En: Revista ius et Veritas, Número 31; Lima.

- Ramírez, C. y Flórez, L. (2006) "Apuntes de inversión extranjera directa: definiciones, tipología y casos de aplicación colombianos”; En: Apuntes de Economía № 8; Cali: marzo 2006; Departamento de Economía - Universidad ICESI. https://www.icesi.edu.co/departamentos/ economia/publicaciones/docs/Apecon8.pdf Consultado: 21 de julio de 2017.

- Rico García-Amado, L. y Kucharz, T. (2013) "Tratados bilaterales de inversiones: Una herramienta fundamental para la globalización neoliberal"; En: Revista El Ecologista $\mathrm{N}^{\circ} 79$; Madrid: http://www.ecologistasenaccion.org/article27101.html\#nb2-5 Consultado: 21 de julio de 2017.

- Rubio, M. (1999) “Estudio de la Constitución Política de 1993. Tomo III”; Lima: Fondo Editorial de la Pontificia Universidad Católica del Perú.

- Saco, V. (2014) "Algunos comentarios sobre la expropiación en el Derecho Internacional de las inversiones"; En: Enfoque de Derecho; Lima: Themis; http://enfoquederecho. com/internacional/algunos-comentarios-sobre-la-expropiacion-en-el- derecho-internacionalde-las-inversiones/ Consultado: 21 de julio de 2017.

- Sumar, Oscar (2014) “¿El Estado debe compensar por expropiar?”; En: Diario Gestión; Lima: 13 de febrero de 2014; http://blogs.gestion.pe/menulegal/2014/02/el-estado-debecompensar-por-expropiar.html Consultado: 21 de julio de 2017.

- Velásquez Meléndez, Raffo (2013) "Expropiación indirecta. Justificación, regímenes, casos, criterios y usos"; En: Revista lus et Veritas N 46; Lima: Julio 2013; Asociación lus et Veritas. 


\section{Sentencias del Tribunal Constitucional del Perú}

Tribunal Constitucional del Perú (1999) Resolución recaída en el expediente Nº541-1999- AA/ TC. Caso Oscar Enrique Morello Silva.

Tribunal Constitucional del Perú (2008) Sentencia recaída en el expediente $N^{\circ}$ 01735-2008- PA/ TC. Caso Shougang Hierro Perú S.A.A.

Tribunal Constitucional del Perú (2010) Sentencia recaída en el expediente N 01405-2010- AA/ TC. Caso Corporación Rey S.A.

Tribunal Constitucional del Perú (2010) Sentencia recaída en el expediente № 0239-2010- AA/ TC. Caso Promotora e Inmobiliaria Town House S.A.C.

Tribunal Constitucional del Perú (2011) Sentencia recaída en el expediente Nº0142-2011- PA/ TC. Caso Sociedad Minera de Responsabilidad Ltda. Maria Julia.

Fecha de recepción: 23 de octubre de 2020

Fecha de aceptación:06 de noviembre de 2020 